\title{
Social partnership - is it 'the only game in town'?
}

\author{
Mary Murphy
}

\begin{abstract}
Abstact This article attempts to analyse some of the experiences of the Irish community and voluntary sector's participation in social partnership. The article explores the politics of social partnership and discusses the implications of participation in social partnership for the potential strategies and choices for the community and voluntary sector. It looks at the outcomes of that participation from the perspective of both its impact on income and other inequalities and its impact on the community and voluntary sector and its relationship with the state, other actors and internal relationships within the sector. Alternatives to social partnership are explored and the article concludes that, while limited, there are specific gains and reasons to 'stay inside'. At the same time, we should be firmly focused on the 'outside' and on alternative alliances, tactics, visions and ideologies.
\end{abstract}

\section{Social partnership in Ireland}

Since 1987, the process of governance in Ireland includes a model of social partnership based on three-yearly economic and social agreements between the government and three pillars - employers, trade unions and farmers. From 1996, the national social partnership process has involved a fourth pillar, the Community and Voluntary Pillar. This widening of the national social partnership process brought about a broadening of the agenda so that equality, poverty and redistribution were more explicit objectives of the later rounds of national agreements. While the social partnership process was also replicated at a local level, this development will not be discussed in this paper.

The Community and Voluntary Pillar includes seven national organizations and the Community Platform. Membership of the 'Pillar' was designated by the government in October 1996, and the Pillar has since defined itself as primarily about social inclusion, equality and poverty. The Community Platform, formed in April 1996, is a self-organized grouping of national organizations that has defined itself as exclusively concerned with 
equality, social inclusion and poverty issues. Members are drawn from a variety of self-representative organizations, single-issue groups and large solidarity type organization. There are 25 national organizations and federations in the Community Platform (four of which have independent access to the Pillar). For some of these organizations principles of community development and the desire to strengthen opportunities for participative democracy are at the core of their rationale for participation in social partnership. The fact that the Pillar and the Community Platform co-exist and overlap has meant that considerable duplication of effort and communication has taken place. Between 1996 and 2001, the Pillar and the Community Platform have spent time trying to forge acceptable working methodologies. ${ }^{1}$ It is worth noting that neither the Pillar nor the Community Platform claim to represent the larger civil society found in the community and voluntary sector.

This paper argues that national social partnership, in so far as it influences budgetary policy and wage policy, has been part of the general policy system that produces income inequality. It also argues that social partnership has little capacity to stem this growing inequality. It asks, if national social partnership arrangements fail to challenge existing levels of income inequality and power imbalances in Irish society, and if they accept the dominant discourses of economic liberalism, are they as much part of the problem as the solution? Furthermore, it asks if alternative strategies that focus on rights, representative democracy or conflict could achieve more positive outcomes in relation to income equality and structural change. The legacy of inequality means that the legitimacy of the social partnership approach is now rightly challenged from within the community and voluntary sector, and continued participation in social partnership is now in question. The paper suggests that while there may yet be some value in having a foot on the inside, we should be aware of the opportunity cost and the price of participation.

\section{Social partnership and inequality}

The five programmes outlined below saw Ireland move from recession in 1987 to record levels of economic growth in 2000. Primarily focused on wage moderation and tax reductions, the national programmes also contain important economic, industrial, agricultural, labour market and social policy commitments.

\footnotetext{
I During this time the Pillar has accepted the Platform is a specific entry route to social partnership and has specific weighting in pillar decision-making processes, this is reviewed periodically. However there is still considerable deadweight in these working arrangements. Some feel it may be more appropriate to converge the two entities. However this is blocked by some of the individual Pillar organizations that wish to maintain the separateness of the two structures.
} 
1987 Programme for National Recovery

1990 Programme for Economic and Social Progress

1994 Programme for Competitiveness and Work

1997 Programme for Inclusion, Competitiveness and Employment

2000 Programme for Prosperity and Fairness

The construction of social partnership since 1987 has been focused on international competitiveness, macro economic stability, tax reductions and employment creation. Nolan et al. (2000, p. 343) comment on the Irish model of 'competitive corporatism' which gives international competitiveness and macro economic stability priority and gives less emphasis to equality than other variants of corporatism. In a recent study, Turner and Wallace (2001) agree with this analysis and argue that the national agreements since 1987 reflect low levels of social solidarity. They cite increased wage disparity, a focus on percentage wage agreements, a greater percentage of lower paid workers and lower proportion of GDP spent on social expenditure, as proof of inequitable outcomes from social partnership. Their analysis mirrors the broad conclusions reached by Kieran Allen (2000) in The Celtic Tiger - The Myth of Social Partnership (see reviews).

In Bust and Boom (2000, p. 352) the authors conclude that net outcome of this process of social partnership was to leave 'inequality of opportunity in terms of social mobility, educational opportunity and risk of poverty stubbornly high'. The benefits of growth were, by and large, divided between industry and the organized and predominantly middle class trade unions. Social protection remains minimal and there has been a weakening welfare effort in terms of the proportion of national income going on social spending.

However, it is important to acknowledge the benefits of the national programmes. In a sense these programmes may have made society fairer because they prevented it becoming even less fair. Nolan et al. (2000, p. 344) argue that social partnership has ensured protection of social rights for the most vulnerable as integration into the global economy proceeded. Social partnership appears to have had benefits for those on lower incomes, both social welfare recipients and wage earners - for example the setting of the minimum wage and the achievement of a priority, minimum income adequacy rate for social welfare payments. Most of the success in this respect has been due to increased employment growth. The National Economic and Social Council (NESC) and other policy advisory and research agencies, including the OECD, have argued that social partnership, specifically through wage restraint, has been central to growth and in turning that economic growth into employment growth and prosperity.

Given this success it would be foolish to argue that material poverty has 
not been reduced and there appears to be some consensus that social partnership does moderate income inequality. This is an important consideration, for there may be few alternative strategies that provide this type of check on the grosser extremes of inequality, evident in the US and Britain in the 1990s. At the same time, however, social partnership has presided over a period of weakening welfare support where the proportion of national income going on social spending has been reduced from 33\% of GNP in 1996 to 24\% of GNP in 1999 (Cantillon and O'Shea, 2001, p. 87).

Combat Poverty Agency (Callan et al., 1999) data are sobering and show two distinct trends of widening income inequality. One trend relates to relative income poverty; in six years the number of households under the $50 \%$ average disposable income poverty line increased by one-third, from $18.4 \%$ in 1994 to $24.9 \%$ in 1998 (Callan et al., 1999). The second relates to widening gaps in income distribution; O Reardon (2001, p. 117) cites how the Irish gini co-efficient increased significantly from 1994 to 1997.

\section{The perspective of the Community and Voluntary Pillar}

The Community and Voluntary Pillar sought entry into social partnership as a means to an end. The outcomes it sought were greater social inclusion and reductions in inequality and poverty. Success has been limited; there has been a clear reduction in consistent poverty (defined as being below a specific income level and experiencing one of 14 specific deprivation indicators, e.g. lack of a warm overcoat or a second pair of shoes). But social partnership has not produced other desired outcomes. This prompts the question as to whether or not the Community and Voluntary Pillar should remain in social partnership. A deeper question might also be asked. Is the participation of the sector in social partnership actually reinforcing and legitimizing existing power differentials? Are we allowing ourselves to be used as a smoke screen within a process that is perpetuating inequalities?

The community and voluntary sector generally, and the Community Platform specifically, are beginning to ask if the participation in social partnership limits their capacity to achieve change through other methods. The Platform is becoming aware of the reality of being swamped within a process over which it has little control. There is a sense of institutional fatigue. The day to day workings of social partnership require ongoing servicing and there are no core resources for this work. For example, in the Programme for Prosperity and Fairness text, it is possible to identify 41 social inclusion implementation processes and 65 overall implementation processes. There is an increasing sense of being distracted away from what originally motivated entry into social partnership. 
Additionally, to legitimate its sometimes questioned involvement in social partnership and maintain a representative mandate, the sector has spent more time on 'collective processes' than other social partners and has had to spend scarce resources on trying to build more effective local/national linkage. There is also the challenge of building common policy platforms. The process of preparing for the Programme for Prosperity and Fairness took four times longer than the actual work of its negotiation. This has had practical implications for the sector as a whole, for individual organizations and for individual workers in those organizations.

\section{The absence of ideological debate}

In a Community Workers Co-operative publication (2001, p. 5) the notion of partnership is analysed in terms of equal participation, co-option and dominant agendas. It is suggested that social partnership is increasingly seen as an end in itself, where the illusion of equality is created through participation rather than through equal outcomes. This debate about social partnership is not confined to the community and voluntary sector, but is also evident within the Irish trade union movement. Partnership is not seen as the most effective game, simply the 'only game'. It is necessary to ask 'has partnership been imposed "as the only game in town" on the community and voluntary sector?'.

There is an illusion of consensus at the negotiation table because there is an absence of ideological debate and this gives the appearance of consensus. Allen suggests 'few have questioned the principles of social partnership which have become the official ideology of the Irish state much as republicanism or Catholicism were in the past' (2000, p. 35). Put simply, the Irish social partnership process does not allow wide debate about redistribution. The experience of the community and voluntary sector's attempts to have widening income inequality even discussed in the government's National Anti-Poverty Strategy serves as a useful example of how difficult it is to influence the agenda.

A prerequisite for entry into social partnership is a shared understanding and this involves accepting an ideological backdrop that underpins the status quo and its related inequality. The dominant economic model is rarely if ever challenged in national policy-making arenas. Indeed, dominant ideologies are reinforced and competitiveness is put forward as the bedrock on which all other policy must be assessed. When neo-liberal ideologies are challenged it is often in the guise of arguments about sustainability or regional balance (CORI, 1999), rather than concern to transform the inherent inequalities they produce.

Emphasis on consensus and finding pragmatic common ground to move 
projects and budgets forward means there is little ideological discussion. Social partnership processes deny the possibility of conflictual dialogue. Instead social partnership prides itself on its problem solving capacity. Consensus and problem solving models work by setting aside ideological differences to allow shared understandings to develop (NESC, 1997). They avoid visioning about the future in order to be pragmatic about the present. There is little actual dialogue between social partners in national agreements, with most cross-communication taking place in formal plenary sessions or bilaterally with government. This not only denies the possibility of ideological discussion but also limits creative approaches to problem solving around inequality issues.

Attempts by the community sector to open up informal dialogue with other pillars have met with resistance. There is some concern that the development of new institutions (National Competitiveness Council, National Partnership Forum) might involve a restructuring of the process of social partnership so that core elements of that process may be placed beyond the reach of the Community and Voluntary Pillar. The Pillar has, for example, been denied a place in the National Competitiveness Council. Hardiman (2000, p. 303) comments negatively on the impact of community and voluntary sector participation in the National Economic and Social Council. "Their presence in NESC makes that body more diffuse in composition and potentially less cohesive in its consensus building on economic priorities. A more inclusive process is a more unwieldy process.'

Those who seek to initiate debate or challenge the consensus, within or on the fringes of social partnership, find that they are rebuked verbally or in writing for going outside the rules of the game. People who raise their voice in dissent are told that they are not playing fair, they are breaking the rules, or they are breaking confidentiality. This subtle game playing takes its toll on key individuals inside the system of partnership. Individual participants report that even though well aware of the dangers of co-option, it is difficult to strike a balance between 'effective tactical game playing inside' and non-conformist tactics or action on the outside. When this is combined with time pressures and other work pressures, there is a danger that the internal dissent that exists is not voiced externally and the silence of apparent consensus becomes deafening.

The end result protects the dominant economic model and status quo. In effect, the victories of the community and voluntary sector tend to be tokenistic and symbolic. For example, the hard fought victory of minimum adequacy for social welfare payments, was worth a mars bar a week to social welfare recipients. Basic social stratification has never been threatened by social partnership. Education, health and housing inequalities have widened over this same period. 
The social partnership model has been criticized as an insider/outsider model that protects insiders at the expense of outsiders. The Community and Voluntary Pillar do not seem to fit this bill. The people they represent gain little from being on the inside. Are they outsiders on the inside? Certainly, the Community and Voluntary Pillar's critical response to Budget 2001 indicates a serious disquiet about the social partners' commitment to social inclusion.

\section{What do we expect from participation and why are we 'inside'?}

The principle of participation is basic to social partnership. However, it is clear that different organizations interpret this principle of participation differently. It is also clear that within the Pillar and Platform, different organizations identify with different types of participation and have different motivations for participation. This leads to different tactics, which may lead to confusion, ineffectiveness and frustration.

Participation can be active, passive or negative. Positive and active participation models range from empowerment and self-mobilization where participation is an active taking of whatever form of power is possible. This includes agenda setting, interactive participation, joint analysis, policy development and actual decision-making. Passive engagement can range from informing a community of what is already decided, to using participation to gather information, to allowing people to express opinions about a pre-determined agenda. Negative participation occurs when our presence is purely tokenistic and when it is used to legitimize policies or outcomes that are clearly not in our favour.

In practice our experience in social partnership has included all the above models of participation. Collectively, those of us within the Community and Voluntary Pillar have been very unclear about our motivation for participation and unclear about what we want from the game - therefore we have a limited capacity to win. We should only consider staying inside partnership if we think we can increase our capacity to win and we are clear about what it is we are trying to win.

If we can increase our capacity to play the game effectively there are valid practical reasons to stay in social partnership. There is learning, information and limited debate. There is some influence over what might otherwise be greater macro inequality. There is some capacity to affect redistributive policies. There is potential for alliances across the social partners regarding the public spending agenda. We can influence policy development by identifying new data, forcing new processes and exposing 
naked self-interest. We have had and will continue to have individual discreet successes.

While there is not an overwhelming case to stay in social partnership neither is there an overwhelming case to leave. The Community and Voluntary Pillar's exit from social partnership is unlikely to make front-page news nor is our departure likely to change the nature of ideological debate in Ireland today. Remembering how hard it was to get a foot in the door, we know that if we leave, the door will be slammed shut behind us. We also know that without alternative strategies and tools, walking away from social partnership will effect little change.

If the sector remains in social partnership, then it needs to be clear about why it is participating, what it expects from participation and the conditions under which it is inappropriate to participate. This should be agreed collectively. If we wish to engage in or aspire towards self-mobilization type participation, we need what many of us have already recognized - leadership, discipline, organization, tactics, allies and energy. A clearer rationale and strategy around participation can only be a valid choice if combined with alternative strategies including conflict, campaigning and rights based approaches. If we cannot develop clear collective strategies around our participation and if we cannot combine our participation with alternative actions, then our participation is likely to be negative. If this is the case, we should do the honourable thing and withdraw.

\section{Alternative strategies}

Participatory democracy requires that parties who are affected by change should be involved at the earliest possible stage in the process of policy making. McCormack (2000) notes if the voice of those who need resources and require elevation in society is not being heard in the formulation, implementation and monitoring of social policy, then it is not surprising that decisions taken about them and their needs are often wide of the mark. While there is a lot of discussion on participation and consultation in the government's White Paper, Supporting Voluntary Activity (2000, see Broderick), there is in practice, very little commitment to resourcing real participation and no great urgency in reforming the policy making system to allow for proper in-depth consultation. Real consultation and participation requires measures that are proactive. This entails putting in place innovative structures and supports.

In 1999, alongside social partnership and representative democracy approaches, direct action and conflict approaches re-surfaced in Ireland to influence the redistribution agenda. Arguably, strike action for increased 
pay by public sector workers such as nurses, the Gardaí (police) and more recently teachers, suggests that direct action can sometimes deliver better results for certain groups than the consensus-building approach of social partnership. From an anti-poverty perspective, given the very limited capacity to organize the poor for conflict style action, social partnership may well be a more powerful tool than conflict or rights approaches. Those dependent on social welfare have little local or national bargaining power in any conflict approach (Allen, 1998). However, international protests at IMF and GATT meetings show the potential for creativity and mass mobilization around social inclusion issues (see review of Klein in this volume).

It is worth noting how wealthier groups, rather than engaging in social partnership, sometimes use the legislative system to vindicate 'their rights' and force government to accede to their agenda. This becomes visible as opposition to planning applications for Traveller halting sites, social housing projects or asylum seekers' reception centres in the more affluent areas of our cities.

Would a judicial rights-based approach offer more than is offered by social partnership to those seeking to eliminate poverty and inequality? In the past there have been some significant victories through the courts - the right to education for autistic children (later successfully appealed by the state) is a recent example. Certainly, the lack of constitutionally based social and economic rights limits this potential, but the full incorporation of International Conventions into Irish law could provide a framework for a rights based approach to be developed. The slow approach to establishing the Republic's Human Rights Commission and the controversy over the appointment of commissioners suggest that government fears a commission that could develop and promote a strong socioeconomic rights approach. A rights framework for the reviewed National Anti-Poverty Strategy is a key demand of the Community and Voluntary Pillar.

\section{Conclusion}

From the perspective of the Community and Voluntary Pillar, social partnership has borne very limited fruit and there has been a considerable opportunity cost in terms of loss of time dedicated to other actions for social change. Public awareness raising, legal challenges, social analysis, networking, conflict and straightforward campaigning, are necessary. Although we might suspect it, we have neither tested nor proven that these alternative strategies are incompatible with social partnership. It is time to put social partnership to the test and to stretch the rules of the game. If having tested the rules of the game, we find that being social partners is 
incompatible with alternative actions, then we should go. However, right now, we need every conceivable route we can find and so, for the time being, the outsiders on the inside should stay where they are.

Mary Murphy is the National Social Policy Officer for the Society of St Vincent De Paul, and previous to this she held the position of Assistant General Secretary for the Irish National Organisation of the Unemployed. As a key actor in both the Community Pillar and Community Platform she was centrally involved in negotiations leading to the Partnership 2000 and PPF National Agreements and is a member of key partnership bodies including the National Economic and Social Forum and the National Economic and Social Council. The views expressed in this article are the author's own.

Address for correspondence: Mary Murphy, 24 Clancy Avenue, Finglas, Dublin 11, Ireland. Tel: + 35318 343994; Email marymur@eircom.net

\section{References}

Allen, K. (2000) The Celtic Tiger - The myth of social partnership in Ireland. Manchester University Press, Manchester, UK.

Allen, M. (1998) The Bitter Word. Poolbeg, Dublin.

Callan, T., Layte, R., Nolan, B., Watson, D., Whelan, T., Williams, J. and Maitre, B. (1999) Monitoring Poverty Trends, Combat Poverty Agency, Dublin.

Cantillon, A. and O'Shea, E. (2001) Social expenditure, redistribution and participation, in S. Cantillon, C. Corrigan, P. Kirby and J. O'Flynn, eds, Rich and Poor, Perspectives on Tackling Inequality in Ireland. Oak Tree Press, Dublin.

Community Workers Co-operative (2001) Strategies for Social Partnership, Strategy Guide 6, Local Development Research and Information Project. CWC, Galway.

CORI (2000) Prosperity and Inequality. CORI Justice Commission, Dublin.

CORI (1999) Democracy and Social Partnership. CORI Justice Commission, Dublin.

Crowley, N. (1997) Frameworks for partnership: emerging models and responses, in Community Workers Co-operative, ed., Partnership in Action. CWC, Galway.

Government Publications (1997) Partnership 2000, Inclusion, Employment and Competitiveness. Stationery office, Dublin.

Government Publications (2000) Programme for Prosperity and Fairness. Stationery Office, Dublin.

Hardiman, N. (2000) Social partnership, wage bargaining and growth, in B. Nolan, P. O'Connell and T. Whelan, eds, Bust to Boom. Institute of Public Administration, Dublin.

McCormack, I. (2000) Meeting and owning change, in CORI, ed., Participation and Democracy; Opportunities and Challenges, CORI Justice Commission, Dublin.

O'Reardon, C. (2001) Equality in the new Irish economy, in S. Cantillon, C. Corrigan, P. Kirby and J. O'Flynn, eds, Rich and Poor, Perspectives on Tackling Inequality in Ireland. Oak Tree Press, Dublin.

NESC (1996) Strategies for the 21 $1^{\text {st }}$ Century. National Economic and Social Council, Dublin. 
Nolan, B. (2000) Income Distribution in Ireland. Combat Poverty Agency/Oak Tree Press, Dublin.

Nolan, B., O'Connell, P. and Whelan, T. (2000) Bust to Boom. The Irish Experience of Growth and Inequality. Institute of Public Administration, Dublin.

Turner, T. and Wallace, J. (2001) The Irish model of social partnership: achievements and limitations, in T. Turner and D. Dart, eds, Irish Employee Relations in the New Economy. Blackhall Press, Dublin. 